\author{
Ks. Radosław Gabrysz* \\ Lublin
}

\title{
STANOWISKO JÓZEFA TISCHNERA WOBEC TOMIZMU
}

\section{Stowa klucze:}

tomizm, synteza tomistyczna, synteza naukowa, teologia spekulatywna, metafizyka, chrześcijaństwo, objawienie chrześcijańskie

\section{Treść:}

I. Koncepcja chrześcijaństwa tomistycznego jako syntezy

II. Struktura tomistycznej teologii spekulatywnej

III. Teologia a metafizyczna koncepcja poznania naukowego

IV. Problem nowej syntezy

Myśl Józefa Tischnera ${ }^{1}$ rozwijała się pod wpływem fenomenologii, ale i filozofii dialogu z pewnymi wątkami egzystencjalizmu. Na kształt filozofii Tischnera, jak przyznaje on sam, duży wpływ miały warunki życia i pracy. W swej biografii naukowej wspomina także o tomistycznych początkach ${ }^{2}$. W rozmowie z Anną Karoń-Ostrowską wskazywał zaś na mistrzów: Ingardena, od którego powziął metodę filozofowania, Husserla, ale i Heideggera.

* Ks. Radosław Gabrysz, kapłan diecezji zielonogórsko-gorzowskiej, doktorant Katedry Etyki Szczegółowej na Wydziale Filozoficznym KUL.

${ }^{1}$ Urodzony 12 marca 1931 roku w Starym Sączu; święcenia kapłańskie - 26.06.1955 rok; studia na wydziale filozofii chrześcijańskiej ATK w Warszawie (1955-1957); 1959 rok egzamin magisterski na podstawie pracy dotyczącej filozofii poznania kard. Merciera; 1963 rok - obrona pracy doktorskiej na temat ,ja" transcendentalnego w filozofii E. Husserla (na seminarium prof. R. Ingardena); prowadzi działalność naukową i duszpasterską, debiutuje w „Znaku” (1966); autor licznych rozpraw i publikacji (m.in. Etyka solidarności, Filozofia dramatu, Myślenie wedtug wartości, Spór o istnienie człowieka); tuż przed śmiercią otrzymuje Order Orła Białego; umiera po ciężkiej chorobie 28 czerwca 2000 roku (por. Z. Kuderowicz, Józef Tischner - jako filozof $i$ etyk, w: Myśli i ludzie. Filozofia XX wieku, t. 1, red. Z. Kuderowicz, Warszawa 2002, s. 149-151. Dokładną biografię opracował: W. Bonowicz, Tischner, Kraków 2001, s. 146, 149, 167, 184-185, 200-201, 476 i 478).

${ }^{2}$ Por. J. Tischner, Myślenie wedlug wartości, Kraków 2002, s. 6. 
Inspirował się filozofią Levinasa i Rosenzweiga. Przyznawał się także do zainteresowania filozofią Hegla ${ }^{3}$.

Tymczasem, ogłoszona przez papieża Leona XIII w dniu 4 sierpnia 1879 roku encyklika Aeterni Patris usankcjonowała, ale i przyśpieszyła pewien ruch umysłowy w tomizmie. Według Wincentego Granata było to, historycznie ujmując, ,trzecie spojrzenie na Tomasza z Akwinu”. W katolickich uczelniach i seminariach dokonywano zatem próby „odczytania na nowo” myśli św. Tomasza z Akwinu, jako filozofii wyróżnionej w Kościele katolickim ${ }^{4}$. Między innymi dlatego, że jak zauważa Etienne Gilson, doniosłość tomizmu tkwi w uwzględnieniu rozumu i wiary $-\mathrm{z}$ właściwymi każdemu $\mathrm{z}$ tych pierwiastków wymogami. W tej optyce współpraca rozumu i wiary nie redukuje względem siebie jednej z tych rzeczywistości do drugiej ${ }^{5}$.

W tę tendencję wpisał się także Sobór Watykański II, który jak ocenia Stefan Swieżawski, był „najbardziej tomaszowym” soborem w historii Kościoła. Po latach jednak stwierdził, że „skończyła się epoka tomistyczna, bo niestety tomizm zwyrodniał. Zamiast być wspaniałą, niczym nie zastąpioną myślą filozoficzno-teologiczną samego św. Tomasza z Akwinu, stał się z biegiem czasu ideologią, która była narzucana”. W Polsce bowiem krytycy Aeterni Patris i w ogóle nawrotu scholastyki w wydaniu tomistycznym używali określenia „filozofia z nakazu”.

Filozofia Tischnera, odległa od metafizycznych rozwiązań tomizmu, spotkała się z gorącą krytyką zwolenników myśli św. Tomasza z Akwinu. Przy czym sam Tischner podjął to wyzwanie i krytyce tomizmu poświęcił wiele uwagi, równocześnie podkreślając, że jego własna refleksja przynależy do myśli chrześcijańskiej ${ }^{7}$. Szczególną dyskusję lat siedemdziesiątych XX wieku wywołał artykuł autora zatytułowany Schylek chrześcijaństwa tomistycznego ${ }^{8}$. $\mathrm{W}$ polemikę zaś zaangażowali się wybitni przedstawiciele ówczesnych środowisk akademickich KUL i ATK - m.in. S. Grygiel, J. Salij, A. Stępień,

3 Por. A. Karoń-Ostrowska, Spotkanie. Z ks. Józefem Tischnerem rozmawia A. Karoń-Ostrowska, Kraków, 2003, s. 53-55 i 74n; T. Gadacz, Filozofia Boga w XX wieku. Od Lavelle'a do Tischnera, Kraków 2007, s. 207; A. Szwed, Tischner jako filozof egzystencji, „Znak” 5(2004), s. 15; J. Tischner, Uprawiam filozofię dobra, w: Rozmowy o filozofii, red. A. Zieliński, M. Bagiński, J. Wojtysiak, Lublin 1996, s. 253.

${ }^{4}$ Por. E. Coreth, P. Ehlen, G. Haeffner, F. Ricken, Filozofia XX wieku, thum. M.L. Kalinowski, Kęty 2004, s. 89; W. Bonowicz, Tischner, dz. cyt., s. 145; W. Granat, O nowe spojrzenie na tomizm, „Znak” 11-12(1948), s. 608.

${ }^{5}$ Por. E. Gilson, Tomizm. Wprowadzenie do filozofii św. Tomasza z Akwinu, thum. J. Rybałt, Warszawa 1998, s. 36-37.

${ }^{6}$ S. Swieżaw ski, Święty Tomasz na nowo odczytany, Poznań 1995, s. 11.

${ }^{7}$ Por. Z. Kuderowicz, Józef Tischner - jako filozof $i$ etyk, dz. cyt., s. 155-156; J. Makowski, Filozofia z wnętrza metafory. Z Markiem Drwięga, Janem Andrzejem Kłoczowskim OP i Karolem Tarnowskim, filozofami, rozmawia Jarosław Makowski, „Kontrapunkt”, 10(2000), http://www.tygodnik.com.pl/ kontrapunkt/48/makow.html (dostęp: 24.06.2013).

${ }^{8}$ Por. J. Tischner, Schytek chrześcijaństwa tomistycznego, „Znak” 1(1970), s. 1-20. Ten artykuł ukazał się później jako fragment Myślenia wedlug wartości (tenże, dz. cyt., s. 201-223). W niniejszej pracy będę odnosił się do tej pozycji, zwłaszcza, że autor zamieścił tam również odniesienia do polemik. 
A. Półtawski, J. Demboróg, M. Gogacz, R. Waszkinel, T. Ślipko, K. Krajewski, S. Swieżawski, M.A. Krąpiec, S. Kamiński, a dyskusja toczyła się głównie na łamach miesięcznika „Znak”, „Tygodnika Powszechnego” oraz „Życia i Myśli”. Debata ta była ważnym wkładem w dyskusję nad kształtem współczesnej filozofii i współczesnego chrześcijaństwa. Poruszone wówczas problemy i dzisiaj mają swój rezonans? .

Celem niniejszego artykułu jest ukazanie stanowiska Tischnera wobec myśli tomistycznej, która rozwijała się w Polsce w trudnym okresie Polski Ludowej i „urzędowego” marksizmu ${ }^{10}$. Przy czym określenia domaga się samo pojęcie kryzysu chrześcijaństwa tomistycznego - w odróżnieniu od kryzysu samego chrześcijaństwa. Przedstawione zostaną tu zatem argumenty, którymi posługiwał się Tischner w polemice $\mathrm{z}$ tomizmem. Skupię się przy tym na tekstach źródłowych, aby zrekonstruować krytyczny wywód. W związku z tym, posłużę się przede wszystkim metodą interpretacji tekstów źródłowych, opracowań i komentarzy.

Charakterystykę stanowiska Tischnera ujmę w czterech zasadniczych częściach. W pierwszej części zajmę się problemem charakterystyki chrześcijaństwa tomistycznego jako syntezy danych Objawienia i filozofii arystotelesowskiej. Wskazane zostaną antynomie powstające na gruncie interakcji tomizmu i chrześcijaństwa, uwidaczniające się w kolejnej części. W punkcie drugim bowiem omówiona zostanie struktura formalno-metodologiczna tomistycznej teologii spekulatywnej, $\mathrm{z}$ ważnym rozróżnieniem pomiędzy logiką teologii spekulatywnej a logiką Objawienia. W części trzeciej zostanie ukazany wpływ metafizycznej koncepcji poznania naukowego na teologię. Pojawi się tu wątek wzajemnego uwikłania filozofii i teologii oraz preferencji tomistycznego punktu widzenia w określeniu podstawowego sensu Objawienia. W części czwartej zarysuję opinię Tischnera na temat problematyczności nowej „potomistycznej” syntezy. W związku z tym idea syntezy zostanie ulokowana $\mathrm{w}$ konfrontacji z nowoczesnymi modelami naukowości. W tym miejscu zostaną wskazane trudności z pogranicza etyki i nauki. Całość wywodu zostanie zwieńczona podsumowaniem, czyli oceną Tischnerowskiej diagnozy kryzysu tomistycznego. $\mathrm{Z}$ powodu niewielkich rozmiarów tego artykułu tylko zdawkowo nawiążę do wypowiedzi polemistów Józefa Tischnera, a stąd też do niektórych punktów zapalnych dyskusji.

\footnotetext{
${ }^{9}$ Por. J. Tischner, Myślenie wedlug wartości, dz. cyt., s. 225-331; Z. Dymarski, Tischnerowskie spojrzenia, „Znak” 5(2004), s. 38; A. Wilczek, W poszukiwaniu prawdy o człowieku. Spór księdza Józefa Tischnera z tomizmem, „Czasopismo Filozoficzne” 4-5(2009), s. 53.

${ }^{10}$ Zdaniem Tischnera tomizm nie dał polskiemu katolicyzmowi narzędzia do krytyki marksizmu, bo tomistyczną zasadą podejścia do marksizmu była synteza, a nie krytyka (por. A. Karoń-Ostrowska, Spotkanie, dz. cyt., s. 89). Według Zbigniewa Stawrowskiego Tischnerowskie analizy i specyficzny język etyczny, przy zręcznym obejściu cenzury, były znaczącym sprzeciwem wobec marksizmu (por. Z. Stawrowski, Tischnerowskie spojrzenia, ,Znak” 5[2004], s. 20n).
} 


\section{KONCEPCJA CHRZEŚCIJAŃSTWA TOMISTYCZNEGO JAKO SYNTEZY}

„Filozofia tomistyczna była, jak wiadomo, filozofią głębokiej syntezy danych Objawienia chrześcijańskiego z podstawowymi danymi filozofii racjonalnej typu arystotelesowskiego. Aby synteza mogła się powieść, trzeba było dokonać pewnej reinterpretacji nie tylko filozofii Arystotelesa, ale także danych religii chrześcijańskiej [...]. W wyniku tej syntezy pojawiła się w historii europejskiej kultury szczególna odmiana teologii i filozofii chrześcijańskiej, znana pod nazwą tomizmu" - pisze J. Tischner ${ }^{11}$. Warto w tym miejscu odnotować wypowiedź Gilsona, który sądzi, że gdyby przedstawienie filozofii św. Tomasza według porządku jego teologii było niemożliwe bez utożsamienia jej z wiarą chrześcijańską, to istotnie lepiej byłoby zaniechać tego porządku. Jednakże nie jest to bynajmniej niewykonalne ${ }^{12}$. Niemniej, w ocenie Tischnera, zestawienie obu porządków - tj. Objawienia oraz filozofii perypatetyckiej - może metaforycznie przypominać zmieszanie dwóch barw. W wyniku tego zabiegu powstaje, owszem, nowa barwa, ale dwie wcześniejsze zatracają się w nowo zaistniałej. Zmianie podlegają bowiem obie barwy wyjściowe. Trzeba jednak w tym miejscu przypomnieć, że jednym z dokonań św. Tomasza była właśnie separacja metodologicznych podstaw filozofii i teologii. Dyskusyjne jest raczej to, czy sam Akwinata konsekwentnie stosował ów podział w swoim piśmiennictwie ${ }^{13}$.

Tomizm powstał w szczytowym momencie rozwoju chrześcijaństwa średniowiecznej „Christianitas”. Bowiem chrześcijańskie było państwo, kultura, filozofia. Jeśli w takim kontekście trudniej było poddać zabiegowi „chrystianizacji” filozofię Platona, to wybór padł na Arystotelesa. Dokonano zatem takiego przetworzenia starożytnej filozofii, aby dało się ją zastosować do zbudowania filozofii chrześcijańskiej, przy równoczesnym zaburzeniu samej idei chrześcijaństwa ${ }^{14}$. Zdaniem Cezarego Wodzińskiego, choć w pracach Tischnera nie widać pogłębionego studium nad myślą grecką, to jednak intuicja owej antycznej filozofii jest tam obecna. Chociaż Tischner nie odmawiał Arystotelesowi znaczącego wkładu w kulturę europejską, to jednak - jak wiadomo był przeciwnikiem włączania tej filozofii w nurt myśli chrześcijańskiej ${ }^{15}$.

W rozumieniu Tischnera zatem synteza tomistyczna opierała się na równoznaczności nurtu religijno-chrześcijańskiego i filozoficzno-arystotelesowskopogańskiego. Tam, gdzie tylko mogło się to powieść, dokonywano substytucji pojęć pochodzących z jednego nurtu przez pojęcia drugiego. Można to

\footnotetext{
${ }^{11}$ Por. J. Tischner, Myślenie wedtug wartości, dz. cyt., s. 202.

${ }^{12}$ Por. E. Gilso n, Tomizm, dz. cyt., s. 18.

${ }^{13}$ Por. J. Tischner, Myślenie wedtug wartości, dz. cyt., s. 202; S. Swieżawski, Dzieje europejskiej filozofii klasycznej, Warszawa - Wrocław 2000, s. 645-648.

${ }^{14}$ Por. A. Karoń-Ostrowska, Spotkanie, dz. cyt., s. 84; S. Swieżawski, Święty Tomasz na nowo odczytany, dz. cyt., s. 56.

15 Por. C. Wodziński, Tischnerowskie spojrzenia, „Znak” 5(2004), s. 30-31;
} A. Karoń-Ostrowska, Spotkanie, dz. cyt., s. 85. 
dostrzec m.in. w przekładalności religijnego pojęcia Boga Stworzyciela na pojęcie arystotelesowskiej Pierwszej Przyczyny ${ }^{16}$. Przy czym, jak sądzi Gilson, Akwinata „czerpał zewsząd”, także z Arystotelesa, by spełnić wytyczone sobie zadanie - czyli podbudować dzieło z założenia teologiczne. W tej perspektywie trudno zatem mówić o równoważności, a tym bardziej równoznaczności czy przekładalności zachodzącej między pojęciami obu nurtów. Stosowniejsze wydaje się stwierdzenie o zachodzącej tu jedynie zależności, polegającej na pomocniczości terminologii proweniencji perypatetyckiej ${ }^{17}$. Jednakże, w ocenie Tischnera, jeżeli można było użyć arystotelesowskiego języka do opisu tajemnic wiary chrześcijańskiej, to tym bardziej warto w tym celu eksplorować język współczesnej filozofii, zamiast za wszelką cenę wskrzeszać , dostojny” tomizm ${ }^{18}$.

„Tomizm zmierzał do pozytywnego «uzasadnienia» i pozytywnego «objaśnienia» tez objawionych za pomocą własnych filozoficznych konstrukcji dowodowych i thumaczących" - stwierdza Tischner ${ }^{19}$. Nasuwa się tu jednak pytanie, czy tym razem autor nie uwzględnił dystynkcji pomiędzy filozofią i teologią, dość wyraźnie przecież wytyczonej przez św. Tomasza już na początku Sumy teologicznej ${ }^{20}$. Choć teologia jest dyscypliną spekulatywną typu filozoficznego, to jednak, według Stanisława Kamińskiego, „nie zależy od filozofii wewnętrznie i obiektywnie", bo św. Tomasz nie używa filozofii do udowodnienia prawd wiary, ale raczej przy ich interpretowaniu i porządkowaniu ${ }^{21}$.

Tym niemniej, zdaniem Tischnera, to właśnie jest typowy dla tomizmu rodzaj syntezy, że mianowicie ta filozofia utworzyła (mniej lub bardziej) jednolitą całość z treścią Objawienia - ze względu na zastępowalność języka Objawienia własnym filozoficznym językiem. Stąd w doktrynie chrześcijańskiej następowało swoiste porządkowanie tez, ich hierarchizacja czy też rozmieszczanie akcentów pod wpływem przeprowadzanej w tomizmie syntezy. Na wizji Boga, w której elementy arystotelizmu splotły się z elementami pochodzącymi z Biblii, tomizm nadbudował teorię tego, co sprawiedliwe i niesprawiedliwe, doskonałe i niedoskonałe, celowe i niecelowe; co prowadzi do Boga i od Niego oddala. W takiej zaś optyce powstaje problem dysjunkcji tego, co filozoficzne, od tego, co ewangeliczne ${ }^{22}$.

\footnotetext{
${ }^{16}$ Por. J. Tischner, Myślenie wedtug wartości, dz. cyt., s. 203.

${ }^{17}$ Por. E. Gilson, Tomizm, dz. cyt., s. 16n; N. M. Wildiers, Obraz świata a teologia. Od średniowiecza do dzisiaj, tłum. J. Doktór, Warszawa 1985, s. 20; J. Ladriere, Nauka, świata $i$ wiara, tłum. A. Paygert, Warszawa 1989, s. 20.

${ }^{18}$ Por. A. Karoń-Ostrowska, Spotkanie, dz. cyt., s. 85n; J. Salij, Duch prawdy, duch wolności, „Znak” 7-8(1970), s. 1005. Chociaż Jacek Salij nie zamierza bronić wyróżnionej pozycji tomizmu, to jednak stawia kwestię: „Czy wszystkie filozofie, po które próbują sięgać katolicy, są jednak w obliczu Objawienia rzeczywiście równorzędne? Obawiam się, że problem jest bardziej skomplikowany niż przedstawia go ks. Tischner". Temu zarzuca bowiem ideologiczny leseferyzm.

${ }^{19}$ J. Tischner, Myślenie według wartości, dz. cyt., s. 203.

${ }^{20}$ Tomasz z Akwinu, Summa theologiae I, q. 1, art. 1.

${ }^{21}$ S. Kamiński, Nauka i metoda. Pojęcie nauki i klasyfikacja nauk, Lublin 1998, s. 316.

${ }^{22}$ Por. J. Tischner, Myślenie wedlug wartości, dz. cyt., s. 203n.
} 
Warta uwzględnienia, w ocenie Tischnera, byłaby tu raczej propozycja hermeneutyczna Paula Ricoeura, tak by rzeczywiście skupić się na objawionym tekście bez tomistycznego dogmatyzmu. Filozof nie może być przecież prorokującym kaznodzieją ${ }^{23}$. Przy czym, zdaje się, że Tischner zauważa rozróżnienie między językiem teologii i filozofii tomistycznej a językiem dogmatu katolickiego, stojącego w pewnym dystansie wobec rozwiązań tomistycznych. Jednak konkluzja tego wywodu skłania się ku temu, że religia katolicka przyjęła na własność tomistyczną syntezę, czego niebezpiecznym rezultatem jest tu specyficznie tomistyczne „zubożenie” chrześcijań$\mathrm{stwa}^{24}$. Oponenci poddawali krytyce to stanowisko, stwierdzając, że Tischner pomieszał tu ,zdrowy” tomizm z jego „wypaczoną" wersją ${ }^{25}$.

Pomimo to, Tischner zmierza do diagnozy, że pomiędzy tezami tomizmu a niektórymi podstawowymi elementami chrześcijaństwa coraz mocniej uwidaczniają się głębokie różnice. Śledząc bowiem dzieje filozofii i nauki, można zaobserwować powolny, ale konsekwentny rozkład tomizmu. Towarzyszył temu rozwój badań nad początkami chrześcijaństwa i podstawowymi źródłami Objawienia. Konfrontacja tych elementów musiała doprowadzić do napięcia czy też kryzysów ${ }^{26}$.

Przeciwieństwo między tomizmem a chrześcijaństwem daje się wykazać na wielu obszarach, także teoretycznych, przede wszystkim zaś w tomistycznej teologii spekulatywnej. Ta sytuacja może stanowić zaś dogodny punkt wyjścia do twórczych poszukiwań nowych sposobów wyrażania rzeczywistości, której bogactwa nie wyczerpują tomistyczne formuły. Co więcej, według Tischnera, warto w tym kontekście pogłębić studia nad augustynizmem, filozofią nowożytną, idealizmem niemieckim - można tam bowiem znaleźć nie mniej frapujące (choć cząstkowe) rozwiązania, które nie zasługują na pochopne odrzucenie ${ }^{27}$.

\section{STRUKTURA TOMISTYCZNEJ TEOLOGII SPEKULATYWNEJ}

Objawienie musiało być dla św. Tomasza z Akwinu czymś co najmniej paradoksalnym. $Z$ jednej strony przynosiło prawdę - pełniąc przynajmniej częściowo rolę nauki. $Z$ drugiej jednak strony, sposób prezentowania prawdy przez Objawienie, odbiegał daleko nawet od ówczesnych modeli naukowości. Stąd też celem naukotwórczej syntezy Akwinaty było ukonstytuowanie nauki

23 Por. P. Ricoeur, Egzystencja $i$ hermeneutyka. Rozprawy o metodzie, thum. E. Bieńkowska, H. Bortnowska, S. Cichowicz i inni, Warszawa 2003, s. 40-41; A. Karoń-Ostrowska, Spotkanie, dz. cyt., s. 90; A. Wilczek, W poszukiwaniu prawdy o człowieku. Spór księdza Tischnera z tomizmem, dz. cyt., s. 59.

24 Por. J. Tischner, Myślenie wedtug wartości, dz. cyt., s. 204; A. KarońOstrowska, Spotkanie, dz. cyt., s. 90.

${ }^{25}$ Por. J. Tischner, Myślenie wedtug wartości, dz. cyt., s. 227.

${ }^{26}$ Por. tamże, s. 204n.

27 Por. A. Karoń-Ostrowska, Spotkanie, dz. cyt., s. 89n; J. Tischner, Myślenie wedtug wartości, dz. cyt., s. 205; tenże, Świat ludzkiej nadziei, dz. cyt., s. 212n. 
objawionej. Rezultatem zaś tych zabiegów była teologia - jako święta doktryna. Źródło antynomii w teologii tomistycznej leży właśnie w głębokiej różnicy, czy nawet przeciwieństwie, między wewnętrzną logiką Objawienia chrześcijańskiego a wewnętrzną logiką teologii tomistycznej. Po latach jednak Tischner osłabił swe stanowisko i posługiwał się raczej terminem „różnica”28.

Teologia spekulatywna jako „zaksjomatyzowany system sądów” wyróżnia pozycję sądów objawionych. Sądem objawionym jest dla teologii spekulatywnej taki sąd teoretyczny, który znajduje się w źródłach Objawienia (uznanych przez Kościół), a dotyczący problematyki zbawienia. Tischner rozumie tu pojęcie aksjomatu systemu dość szeroko. Jego zdaniem sądy objawione można potraktować jako aksjomaty systemu, ponieważ są pewnikami teologii, a zatem nie chodzi tu o warunki stawiane przez współczesną Tischnerowi metodologię ani też o poprawną aksjomatyzację klasycznej filozofii, która w myśl szkoły lubelskiej jest niemożliwa do spełnienia ${ }^{29}$.

Zdaniem Tischnera już w średniowieczu było kilka możliwości co do wyboru modelu dla objawionych sądów. Współcześnie zaś można poszukać modelu „aktualnie w nauce obowiązującego”. Pojawia się tu jednak, jak się zdaje, problem odpowiedniości takiego modelu nauki dla teologii i retorycznej kwestii: czy istnieje dziś jeden przekonujący i satysfakcjonujący wszystkich uczonych model nauki? W tomizmie jednak, jak sądzi Tischner, ów model można odnaleźć w samym układzie traktatów teologii spekulatywnej: na czele stoi traktat o Jednym Bogu (poprzedzony argumentami za istnieniem Boga), następnie: traktat o naturze Boga, o Trójcy Świętej, o relacji Boga do świata, o człowieku, o jego sprawach ostatecznych. Ten układ jest ilustracją ontologicznych związków między bytami: Absolutem a Jego stworzeniem ${ }^{30}$.

Skoro Absolut jest metafizyczną racją wszystkiego, nauka o Absolucie będzie podstawą innych traktatów teologii tomistycznej, szczególnie o Bogu Wcielonym i o człowieku. Źródłem schematu teologii spekulatywnej byłby tu zatem schemat metafizyki. Idea uniwersalnej dedukcji wniosków z kluczowej tezy lub kluczowej intuicji, inspirująca formę „filozofii pierwszej”, narzucała bowiem także formę teologii spekulatywnej ${ }^{31}$.

W jaki sposób zatem wskazać istotę sądu objawionego z punktu widzenia logiki Objawienia, a nadto: jak określić podstawowy schemat formalny Objawienia przez tę logikę wyznaczany? Z chrześcijańskiego punktu widzenia sądem objawionym jest taki sąd, który był przedmiotem asercji Jezusa. „Gdybyśmy popatrzyli na całość Objawienia jako na jednolity system logiczny, to jego podstawową partią okazałaby się nie nauka o Jednym Bogu,

${ }^{28}$ Por. tenże, Myślenie wedlug wartości, dz. cyt., s. 207; A. Karoń-Ostrowska, Spotkanie, dz. cyt., s. 84.

${ }^{29}$ Por. J. Tischner, Myślenie według wartości, dz. cyt., s. 207; P. Garbacz, Aksjomatyzacja, w: Powszechna Encyklopedia Filozofii $1(A-B)$, red. A. Maryniarczyk, Lublin 2000, s. 130-132.

${ }^{30}$ Por. J. Tischner, Myślenie wedtug wartości, dz. cyt., s. 208.

${ }^{31}$ Por. tamże, s. 208; W. Świerzawski, Teologia spekulatywna i egzegeza biblijna uśw. Tomasza z Akwinu, „Znak” 1(1970), s. 46. 
jak w tomistycznej teologii spekulatywnej, ale nauka o Jezusie i o tym, w co On wierzył i innym do wierzenia podawał", a co było głoszone jako kerygmat biblijny lub to, co przezeń wyznaczane ${ }^{32}$. Ponadto, wedle opinii Tischnera, w logice Objawienia należy mocniej uwzględniać wątek temporalny, a zatem w tej logice istotny jest watek rozwoju. Ta koncepcja z kolei wrasta korzeniami $\mathrm{w}$ tradycję heglowską ${ }^{33}$. Jednak pojawia się tutaj trudność dotycząca użycia przez Tischnera sformułowania „logika Objawienia”. Czy chce ją rozumieć podobnie szeroko jak pojęcie „aksjomat systemu”? Być może chodzi tu o rodzaj ogólnej metodologii dla teologii.

Tischner wyprowadza konstatację, że wewnętrzna logika Objawienia nie jest partykularyzacją logiki metafizyki, ale szczególnym przykładem logiki aksjologicznej, logiki wartości czy też „logiki wiary”. Antynomia wewnętrznej logiki Objawienia chrześcijańskiego i wewnętrznej logiki spekulatywnej teologii tomistycznej wynika bowiem z syntezy dwóch różnych struktur logicznych: metafizycznej, w której obowiązuje formalny schemat „od zasad do wniosków”, oraz aksjologicznej, z obowiązującym schematem jakościowym - „kto uznał i co uznał”. Powstające tu trudności, dotyczące rozumienia przez Tischnera pojęcia „antynomia”, prawdopodobnie jednak sam autor odkrył, skoro - jak zaznaczono wyżej - po latach „wythumaczył” termin ,antynomia” jako „różnica”34. W tle tej kwestii pojawia się zaś „gilotyna Hume'a", przecinająca jakiekolwiek związki logiczne między zdaniami i normami. Nie można bowiem wnioskować na podstawie „tego, co jest” „to, jak być powinno” (is-ought problem), a zatem - odnosząc to do myśli Tischnera - „sprzeczność” byłaby tu terminem nieadekwatnym ${ }^{35}$.

Tymczasem, dokonując krytyki tomistycznej teologii spekulatywnej, Tischner zauważa głęboką destrukcję schematu aksjologicznego: oto Jezus, będący aksjologicznym fundamentem Objawienia, jest dla teologii spekulatywnej tomizmu tylko jednym z kolejnych „wniosków” teologicznych ${ }^{36}$.

\footnotetext{
${ }^{32}$ J. Tischner, Myślenie wedlug wartości, dz. cyt., s. 209; por. P. Ricoeur, Egzystencja i hermeneutyka, dz. cyt., s. 41. W ramach swej hermeneutyki autor uwydatnia rozróżnienie czy wręcz antynomię między religią a wiarą.

${ }^{33}$ Por. A. Karoń-Ostrowska, Spotkanie, dz. cyt., s. 85; J. Tischner, Świat ludzkiej nadziei, dz. cyt., s. 218.

${ }^{34}$ „Antynomia to przeciwieństwo, to sprzeczność, to napięcie, jakie wytwarzają między sobą antypody nie do pogodzenia. Antynomia to jednak także źródło wyjścia poza ramy dotychczasowej teorii" (J. Tis chner, Myślenie wedtug wartości, dz. cyt., s. 205). Zdaniem Antoniego Stępnia nie można tu mówić o antynomii. „Tischner nie wykazał, że między teologią tomistyczną a Objawieniem («logiką Objawienia») zachodzi sprzeczność. Nie ma takiej sprzeczności między teocentryzmem a chrystocentryzmem czy między metafizyką a aksjologią (...). Sprzeczność taka może zaistnieć jedynie na gruncie pewnej filozofii lub teologii, którą Tischner - świadomie lub nieświadomie - czytelnikowi zdaje się podsuwać. To jednak nie obciąża tomizmu. Różność nie wystarcza do antynomii” (A. Stępień, Przedwczesne podzwonne tomizmowi?, „Znak” 7-8[1970], s. 999n).

${ }^{35}$ Por. D. Hume, A Treatise of Human Nature, Oxford 1965, s. 469; G.E. Moore, Zasady etyki, thum. C. Znamierowski, Warszawa 2003, s. 15n.

${ }^{36}$ Por. J. Tischner, Myślenie wedlug wartości, dz. cyt., s. 209n.
} 


\section{TEOLOGIA A METAFIZYCZNA KONCEPCJA POZNANIA NAUKOWEGO}

Najbardziej charakterystycznym elementem syntezy tomistycznej jest wyjaśnienie, tłumaczenie, ewentualnie także uzasadnienie Objawienia za pomocą pojęć i tez filozofii arystotelesowskiej ${ }^{37}$. W ten sposób - co jest raczej tischnerowskim zarzutem ideologicznym - świat pogańskiej metafizyki i jej aparat pojęciowy stał się paradoksalną racją wyjaśniającą dla świata chrześcijańskiego Objawienia ${ }^{38}$. „Oglądany” przez pryzmat tych pojęć Bóg odsłania się jako metafizyczno-naukowa zasada ostatecznego wyjaśnienia świata. Bóg występuje w ramach scholastyczno-tomistycznej metafizyki nie tylko jako jej temat, lecz nade wszystko jako element wyjaśniający. Terminem „Bóg” metafizyk wyjaśnia bowiem tajemnice, jakich dostarcza ten świat ${ }^{39}$.

Teologia tomistyczna jest $\mathrm{w}$ swoich rudymentach nauką dedukcyjną. Charakterystyczne jest, że dostęp do teologii mają nie tylko prawdy objawione, ale i tzw. „oczywiste tezy rozumowe”, o których Objawienie milczy, ale które to nie nastręczają wątpliwości „rozumowi naturalnemu” ${ }^{, 40}$. Zresztą pojęcie oczywistości ma, jak się wydaje, tomistyczną proweniencję. W tym punkcie Tischner stawia pytanie o następstwo takiego przenikania teologii przez filozofię ${ }^{41}$. Owa krytyka metafizycznej spekulacji, spotkała się jednak w tym punkcie z zaciekłą polemiką (Krąpiec, Kamiński). Samemu Tischnerowi zarzucano przy tej okazji idealizm, natomiast Tischner (,sokratejski ironista") replikował apologią idealizmu, jako filozofii, która nie może być skazana na ateizm, co do swoich konsekwencji ${ }^{42}$.

Efektem tomistycznego podejścia jest zmiana ogólnego znaczenia filozofii uwikłanej w teologię. Stąd pojęcia i tezy filozoficzne, potraktowane jako przesłanki wyjaśniające, thumaczące czy dowodzące dla wniosków o charakterze teologicznym, nabierają tym samym sensu teologicznego. Wnikając we wnętrze teologii, filozofia podlega procesowi subtelnej zmiany znaczenia - teologizacji. I tak na przykład: jeśli w optyce tomizmu przemia-

\footnotetext{
${ }^{37}$ Wydaje się, że nie chodzi tu o pogląd, według którego Objawienie „zniknie” wtedy, gdy przezwyciężona zostanie filozofia perypatetycka, z której byłoby wyprowadzane, ale raczej o problem znajdowania racji wyjaśniającej-wspierającej (racjonalnej argumentacji) w tej filozofii. Objawienie nie może zniknąć, gdyż - w rozumieniu Tischnera - jest aksjomatem („objawiony sąd”), stąd też genetyczne dane (treści) są zawarte w Objawieniu, a nie w filozofii arystotelesowskiej. Gdyby zatem została przezwyciężona ta filozofia, teologia spekulatywna na niej wsparta nie straciłaby swej treści (Objawienie), ale ,jedynie” racjonalną konstrukcję lub wyjaśnienie swej struktury i ten typ argumentacji, który czerpie z arystotelizmu.

${ }^{38}$ Por. Z. Kuderowicz, Józef Tischner - jako filozof $i$ etyk, dz. cyt., s. 156; J. Tischner, Myślenie wedlug wartości, dz. cyt., s. 217.

${ }^{39}$ Por. J. Tischner, Świat ludzkiej nadziei, dz. cyt., s. 212.

${ }^{40}$ Tomasz z Akwinu, Summa theologiae I, q. 1, art. VII.

${ }^{41}$ Por. J. Tischner, Myślenie wedtug wartości, dz. cyt., s. 210; A. KarońOstrowska, Spotkanie, dz. cyt., s. 84.

${ }^{42}$ Por. K. Tarnowski, Wiara i myślenie, Kraków 1999, s. 256-257; A. KarońOstrowska, Spotkanie, dz. cyt., s. 85.
} 
na eucharystyczna ma charakter przemiany substancjalnej, to na skutek teologizacji, także nasz świat przejawia pewną substancjalistyczną strukturę. Stąd krytyka substancjalistycznych teorii materii musiała, choćby pośrednio, uderzyć w teologię katolicką - mówi Tischner ${ }^{43}$.

Tymczasem we wzajemnym promieniowaniu na siebie teologii i filozofii można dostrzec źródła kryzysu teologii katolickiej na przełomie lat sześćdziesiątych i siedemdziesiątych XX wieku. Z tym, że Tischner dostrzega jeszcze pewien paradoks. Oto bowiem tomizm twierdził, że jest filozofią służącą teologii: philosophia ancilla theologiae. Jednak proces teologizacji doktryny filozoficznej doprowadził do charakterystycznej „zamiany ról”. W pewnym momencie okazało się bowiem, że jest odwrotnie: teologia stała się służebnicą filozofii. Świadectwem tego były zresztą niektóre filozoficzne pozycje na indeksie ksiąg zakazanych. „Znalazły się tam bowiem nazwiska przedstawicieli tych kierunków filozoficznych, które stały w opozycji nie tyle do chrześcijaństwa, ile właśnie do realizmu tomistycznego (np. Kartezjusz, Malebranche, a nawet Bergson)" ${ }^{\text {"44 }}$. Komentując tę wypowiedź, z jednej strony wydawać by się mogło, że są to akurat przykłady tego, że filozofia powinna być służebnicą teologii, a ujęci przykładowo filozofowie nie spełniali tego standardu. Ich poglądy filozoficzne bowiem niosły niebezpieczne konsekwencje dla teologii. Im bardziej autorzy oddalali się od uznanej (,pewnej”) filozofii (nie tylko przecież tomistycznej ${ }^{45}$ ), tym bardziej ich prace mogły odbiegać w konsekwencjach teologicznych od uznanej doktryny - bowiem w myśl Arystotelesa, przywołanego przez św. Tomasza: „mały błąd na początku jest wielkim błędem na końcu" ${ }^{\prime 4}$. Z drugiej strony, zdaje się, że Tischner dostrzega $\mathrm{w}$ tym fragmencie wywodu taką rolę teologii, która dość dyspozycyjnie (służebnie) reflektuje i sprawdza różne nurty filozofii, które nie są zbieżne z jej własnymi (przyjętymi) filozoficznymi podstawami - być może stąd mowa o „zamianie ról”: teologia służyła obroną sprzymierzonej z nią filozofii ${ }^{47}$. Można tu przedstawić i to rozumienie owej „zamiany ról”, że poparciem takiego stanowiska byłoby potępienie jakiejś teologii za brak zgodności z filozofią.

Niemniej, Tischner dostrzega problem preferencji pewnego szczególnego punktu widzenia prymarnego sensu Objawienia. Możemy bowiem zapytać, co było ukrytym założeniem umożliwiającym fakt przenikania tez filo-

\footnotetext{
${ }^{43}$ Por. J. Tischner, Myślenie wedlug wartości, dz. cyt., s. 211n, 229. Ta refleksja spotkała się z repliką Stępnia, Salija i Półtawskiego, którzy domagali się od Tischnera sprecyzowania stanowiska. Tischner zastrzega jednak, że nie utożsamia teologizacji z dogmatyzacją.

${ }^{44}$ Tamże, s. 213.

45 Przykładem może być choćby zgoda Kościoła na skotyzm, wykładany zwłaszcza w szkołach franciszkańskich. „Nikt nie powinien usuwać w cień innych systemów katolickich" (W. Granat, O nowe spojrzenie na tomizm, dz. cyt., s. 608).

${ }^{46}$ Św. Tomasz, De ente et essentia, w: M.A. Krąpiec, Byt i istota. Św. Tomasza „De ente et essentia”. Przektad i komentarz, Lublin 2001, s. 9.

47 Por. J. Tischner, Myślenie wedlug wartości, dz. cyt., s. 213; A. KarońOstrowska, Spotkanie, dz. cyt., s. 89.
} 
zofii przez tezy religii i na odwrót? Tischner stwierdza, że było to przeświadczenie, że pomiędzy podstawowym sensem sądów filozofii - zwłaszcza sądów metafizyki, a podstawowym sensem sądów pojawiających się w źródłach Objawienia nie ma zasadniczej różnicy. Zachodzi tu pytanie o następstwa preferencji sądów teoretycznych i „esencjalnych”. Zdaniem Tischnera jest to konsekwentnie metafizyczne podejście interpretacyjne do źródłowych tekstów chrześcijaństwa ${ }^{48}$.

Interpretując bowiem tekst objawiony, usiłowano wydobyć z nich coś na wzór drugiej metafizyki, która od pierwszej miała się różnić odrębnością podstaw epistemologicznych. W pierwszej metafizyce podstawą był rozum naturalny, a w drugiej - wiara. Analizując wypowiedź: „Jestem, który jestem", Gilson odczytywał w niej objawienie tezy filozoficznej, że do istoty Boga należy Jego istnienie ${ }^{49}$. Dążąc do wydobycia z Objawienia nauki analogicznej do metafizyki, spekulatywna teologia tomistyczna pomijała w nim całą aksjologię, a tymczasem dla pierwotnych gmin chrześcijańskich Objawienie nie było żadną nową metafizyką, ale raczej nową wizją wartości i związków między wartościami, głównie etycznymi. To wartości bowiem fascynowały i odradzały ludzi. Przy czym wizja wartości nie była w Ewangelii prezentowana poprzez sądy kategoryczne typu ,a jest $k$, ale poprzez konkretne obrazy - wnioskuje Tischner ${ }^{50}$. Dlatego właśnie spór o teorię Kopernika, Galileusza, ewolucjonizm to, zdaniem Tischnera, wypadki ilustrujące konsekwencję preferowania przez tomistyczną teologię metafizycznego sensu Objawienia. Stąd też filozofia tomistyczna, uwikłana w religię, doprowadziła do sytuacji kryzysowej. Ale kryzys ten nie jest kryzysem chrześcijaństwa. To kryzys pewnej historycznej wersji interpretacyjnej chrześcijaństwa. Płynie stąd ostrzeżenie dla filozofów, w tej liczbie dla tomistów, jeżeli jeszcze są przekonani, że czas nie zdezaktualizował pewnych rudymentów kierunków filozofii przez nich uprawianych ${ }^{51}$.

\footnotetext{
${ }^{48}$ Por. J. Tischner, Myślenie wedlug wartości, dz. cyt., s. 215.

${ }^{49}$ Por. E. Gilson, Tomizm, dz. cyt., s. 45-47; J. Tischner, Myślenie wedlug wartości, dz. cyt., s. 215.

${ }^{50}$ Por. J. Tischner, Myślenie wedlug wartości, dz. cyt., s. 215. Można tu jednak poczynić dwa zastrzeżenia. Po pierwsze: jeśli nawet odczytujemy entuzjazm w podjęciu nowych - chrześcijańskich wartości przez pierwsze gminy chrześcijańskie, to czy nie da się tam dostrzec żadnej metafizyki? Zdaje się bowiem, że jej potrzeba stawała się coraz to bardziej nagląca (w konfrontacji ze ,światem"). Prawdopodobnie Tischnerowi chodzi tu przede wszystkim o dominantę wartości u pierwszych chrześcijan. Po drugie: zdaje się, że Tischnerowi nie tylko nie odpowiadała etyka tomistyczna, ale tomizm w ogóle - stąd mówi o schyłku chrześcijaństwa tomistycznego, a nie tylko etyki tomistycznej.

${ }^{51}$ Por. J. Tischner, Myślenie wedlug wartości, dz. cyt., s. 216; A. KarońOstrowska, Spotkanie, dz. cyt., s. 82; J. Tischner, Spowiedź rewolucjonisty. Czytajac „Fenomenologię ducha” Hegla, Kraków 1993, s. 185n.
} 


\section{PROBLEM NOWEJ SYNTEZY}

Tischner, diagnozując koniec syntezy tomistycznej, bada możliwości nowej syntezy, w której pojęcia współczesnej nauki i filozofii mogłyby w bardziej satysfakcjonujący sposób wyjaśniać ideę Objawienia. Rozpatruje postulat częściowej zmiany materiału syntezy przy jej niezmienionej formie. Stąd jednak rodzi się pytanie: czy koncepcja filozofii chrześcijańskiej jako filozofii wyjaśniającej jest współcześnie do utrzymania i czy wytrzymuje krytykę? Nadto pojawia się wątpliwość, czy rozkład syntez tomistycznych poszedł tak daleko, że sama idea syntezy mu uległa? Tischner stoi raczej na stanowisku, że owszem, ów rozkład poszedł za daleko i za głęboko ${ }^{52}$.

W perspektywie bowiem współczesnego modelu naukowości koncepcja filozofii jako nauki syntetyzującej straciła swą atrakcyjność, ale i - co gorsza - zrozumiałość. Skoro zatem synteza tomistyczna jest z racji ściśle teoretycznych niemożliwa do urzeczywistnienia, co więcej - niemożliwa do konsekwentnego wyobrażenia, to wyznaczenie filozofii chrześcijańskiej maksymalistycznego zadania, podobnego do tomistycznej syntezy, jest głębokim nieporozumieniem, ponieważ postawiłoby taką filozofię na marginesie współczesnego życia naukowego - konfirmuje Tischner ${ }^{53}$.

Konkretyzując swe stanowisko, Tischner stwierdza, że z punktu widzenia współczesnej idei poznania naukowego koncepcja syntezy wyjaśniającej jest dla nauki bez znaczenia. Twierdząc tak, Tischner zdaje się podążać w stronę pozytywistycznej wykładni nauki ${ }^{54}$. W ciągu ostatnich wieków uległa radykalnej przemianie sama idea poznania naukowego. Kierunek tych zmian wyznaczały osiągnięcia matematycznego przyrodoznawstwa. Pojawiło się ponadto wielu krytyków tradycyjnego pojęcia nauki: Kartezjusz, Kant, pozytywiści, przedstawiciele filozofii analitycznej, fenomenologowie ${ }^{55}$.

W wyniku podejścia krytycznego zaostrzyły się wymagania stawiane pojęciu ścisłości i rzetelności naukowej. O ile dla tomizmu poznanie było istotowo związane $\mathrm{z}$ wykraczaniem poza zjawisko tu i teraz dane, o tyle współczesna nauka chce wiedzieć mniej, lecz pewniej - nie wychodząc poza ramy doświadczenia. Tischner zauważa, że pozafenomenalny świat natur, racji, zasad, pryncypiów metafizycznych stał się współcześnie niezrozumiały dla nauki. Powodem takiej sytuacji nie jest intelektualny marazm uczonych, ale konsekwentna realizacja aksjomatu współczesnej nauki: nie wychodzić

\footnotetext{
${ }^{52}$ Por. J. Tischner, Myślenie według wartości, dz. cyt., s. 217; tenże, Świat ludzkiej nadziei, dz. cyt., s. 213.

${ }^{53}$ Por. tenże, Myślenie wedlug wartości, dz. cyt., s. 218.

${ }^{54}$ Por. A. Chalmers, Czym jest to, co zwiemy nauka? Rozważania o naturze, statusie i metodach nauki. Wprowadzenie do współczesnej filozofii nauki, thum. A. Chmielewski, Wrocław 1993, s. 23.

${ }^{55}$ Por. J. Tischner, Myślenie wedtug wartości, dz. cyt., s. 218; tenże, Świat ludzkiej nadziei, dz. cyt., s. 213.
} 
poza możliwe doświadczenie ${ }^{56}$. Problem w tym, czy stanowisko Tischnera, sytuujące się naprzeciw maksymalistycznych syntez, nie grawituje nadmiernie w stronę postawy tzw. indukcjonizmu naiwnego. Nawet w rozwoju pozytywizmu i jego kolejnych fazach okazywało się (także w ramach krytyki), że każda teoria naukowa musi jednak zawierać pewne składniki teoretyczne, czyli niedoświadczalne ${ }^{57}$.

Kiedy jednak współcześnie podejmuje się próby wskrzeszania starych koncepcji syntetycznych o tomistycznej proweniencji, to takie próby muszą być skazane na niezrozumienie ze strony naukowej ${ }^{58}$. Jeśli bowiem pewne syntezy wyjaśniające czy też różne kombinatoryki pozwalają myśleć dany przedmiot, to równocześnie nie pozwalają niczego z przedmiotu poznać. Trzeba tu jednak ulokować zastrzeżenie Swieżawskiego, że skoro w nauce zachodzą zmiany, to także pewne modele (np. fizyki mechanistycznej) przestają obowiązywać - przynajmniej na gruncie pewnych fragmentów. Inne zaś teorie naukowe ulegają procesowi popperowskiej falsyfikacji. Niewykluczone zresztą, że temu procesowi mogą ulec także aktualne odkrycia i ich teoretyczna interpretacja. Stąd zaś wypływałby wniosek, iż wyników nauki nie należy przeceniać lub absolutyzowac ${ }^{59}$.

$\mathrm{Z}$ pogranicza nauki i etyki nauki wyłania się problem idei takiej nauki syntetyzującej, która byłaby określona jako podstawowa norma dla całej nauki chrześcijańskiej, bowiem zawierałaby w sobie pewną dwuznaczność w aspekcie etycznym. Jeżeli zatem aktem o znaczeniu naukowo-chrześcijańskotwórczym byłaby synteza, która wyjaśnia treści Objawienia za pośrednictwem danych nauki i filozofii, to - „pytając” Tischnera - co by się stało, gdyby postęp w nauce znalazł się w opozycji wobec chrześcijaństwa? Oczywiste jest bowiem, że system tomistyczny - na pewnych odcinkach swoich dociekań lub ustaleń (m.in. logicznych, fizycznych) nie musi być zabarwiony (indoktrynowany) chrześcijaństwem, tak jak to można wyczytać w tischnerowskiej krytyce. Przecież gdyby tak było, to wtedy na przykład upadek średniowiecznego obrazu świata pociągnąłby za sobą chrześcijaństwo. Nadto sam Tischner określa tu pojęcie syntezy składające się z kilku członów: „akt naukowo-chrześcijańsko-twórczy". Jej elementy mogą, a nawet powinny zachować właściwy sobie charakter $^{60}$. Tymczasem Tischner dostrzega tu ryzy-

${ }^{56}$ Por. tenże, Myślenie wedtug wartości, dz. cyt., s. 218-219; tenże, Świat ludzkiej nadziei, dz. cyt., s. 216-218; J. Ży ciński, Ułaskawianie natury, Kraków 1992, s. 56n.

${ }^{57}$ Por. A. Chalmers, Czym jest to, co zwiemy nauka?, dz. cyt., s. 23-25.

${ }^{58}$ Skądinąd daje się dostrzec relatywnie wiele (także krytycznych) odniesień do Akwinaty we współczesnej filozofii nauki, zwłaszcza gdy idzie o relacje między nauką a wiarą (por. np.: J. Życiński, Bóg i ewolucja. Podstawowe pytania ewolucjonizmu chrześcijańskiego, Lublin 2002, s. 83, 118, 124, 135, 137-139; M. Heller, Ostateczne wyjaśnianie wszechświata, Kraków 2008, s. 169, 171-175, 179n).

${ }_{59}$ Por. J. Tischner, Myślenie wedtug wartości, dz. cyt., s. 219; S. Swieżawski, Święty Tomasz na nowo odczytany, dz. cyt., s. 53n.

${ }^{60}$ Por. J. Tischner, Myślenie wedlug wartości, dz. cyt., s. 219; N.M. Wildiers, Obraz świata a teologia, dz. cyt., s. 20, 93: „Rozejście się nauki i religii oznaczało dla obu 
ko lęku lub podejrzliwości czynionej z pozycji takiej syntezy wyjaśniającej pod adresem postępu w nauce. Owszem, nigdy nie wiadomo czyją stronę poprze nowe odkrycie w nauce. $\mathrm{Z}$ kolei zestawienie postępu $\mathrm{z}$ równoczesnym pragnieniem syntezy jawi się jako coś pozbawionego charakteru rewolucyjnego, podsumowuje Tischner ${ }^{61}$.

Sytuacja ogólnej syntezy naukowej jest zatem złożona. Zgodnie z postulatem pozytywistów synteza wyników nauki miała być podstawowym zadaniem filozofii. Wcześniej filozofia miała dawać całościowe spojrzenie na świat. Jednak współcześnie sytuacja filozofii zmieniła się radykalniej - diagnozuje Tischner. Miejsce uniwersalnych syntez zajęły różne „mikrosystemy", dotyczące pewnych dziedzin rzeczywistości. Idea syntezy okazała się bowiem zbyt wieloznaczna. Przy czym, nawet po wyeliminowaniu wieloznaczności, okazuje się, że warunki syntezy uniwersalnej są niemożliwe do spełnienia. W związku z tym wielu filozofów wybrało drogę pozytywnych analiz pewnych wykrojonych obszarów rzeczywistości, dbając jedynie o koherentność swych teorii ${ }^{62}$.

\section{PODSUMOWANIE}

Józef Tischner, mówiąc o schyłku chrześcijaństwa tomistycznego, nie stwierdza kryzysu chrześcijaństwa jako takiego, ale jego tomistycznej posta$\mathrm{ci}^{63}$. Wywód autora, choć w zamiarach deskryptywny, ma jednak doniosłość postulatywną. Należy odrzucić tomizm, ponieważ staje się coraz mniej zrozumiałą koncepcją - zwłaszcza wobec współczesnych modelów nauki. Tischner zatem stoi na stanowisku odkrywcy nieprzezwyciężalnych antynomii tez tomizmu i tez chrześcijaństwa. Przy czym owa antynomia, owa kryzysowa sytuacja może stanowić punkt wyjścia dla nowych koncepcji. Jest to tym bardziej zrozumiałe, że filozofia tego myśliciela rozwijała się pod wpływem innych niż tomizm inspiracji, o których wspomniałem we wstępie.

W tym miejscu często podnosi się kwestię, czy Tischner krytykował poglądy samego Akwinaty, czy raczej współczesną sobie szkołę tomistyczną - zwłaszcza, że rzadko odwoływał się wprost do św. Tomasza z Akwinu ${ }^{64}$. W samym tomizmie uwidacznia się przecież wewnętrzny podział, czasem lokalizujący stanowiska dość biegunowo, jak w przypadku tomizmu egzystencjalnego (Krąpiec) i - nawiązującego do Kanta - tomizmu transcenden-

stron, jak miało się później okazać, uwolnienie. Kosmologia wyzwoliła się z uścisku teologii, a teologia była zmuszona (...) zerwać z przestarzałym obrazem świata".

${ }^{61}$ Por. J. Tischner, Myślenie wedlug wartości, dz. cyt., s. 219n.

${ }^{62}$ Por. A. Einstein, Pisma filozoficzne, thum. K. Napiórkowski, Warszawa 2001, s. 60-63; J. Tischner, Myślenie wedlug wartości, dz. cyt., s. 220.

${ }^{63}$ Por. Z. Kuderowicz, Józef Tischner-jako filozof i etyk, dz. cyt., s. 155.

${ }^{64}$ Por. J. Tis chner, Myślenie wedlug wartości, dz. cyt., s. 210; tamże, s. 227: „Sądziłem jednak, że gdy idzie o ostateczne źródło teoretyczne tomistycznego chrześcijaństwa (...), to pod tym względem nie ma istotnych różnic między poszczególnymi kierunkami w tomizmie”. 
talizującego (Rahner, Balthasar) ${ }^{65}$. Zresztą $\mathrm{w}$ polemice $\mathrm{z}$ szeroko rozumianym tomizmem Tischner zdaje się równie szeroko, czy wręcz dość swobodnie, szafować takimi terminami, jak „metafizyka”, „ontologia”, czy wreszcie nomen omen samym pojęciem „tomizm”66. Choć Tischner jest podejrzewany o utożsamianie nauki św. Tomasza i tomistów, to jednak zdecydowanie temu zaprzecza. Jednak równocześnie feruje generalny zarzut braku samodzielnej metody pod adresem tego nurtu filozofii. Diagnoza Tischnera sięga głębiej: oto tomizm wypacza chrześcijaństwo i zamyka świat Objawienia we własnych konstrukcjach pojęciowych ${ }^{67}$.

Stanowisko autora Myślenia wedlug wartości spotkało się z krytyką zwolenników tomizmu, dla których, jak sądzi Zbigniew Kuderowicz, filozofia św. Tomasza z Akwinu była ,jedynie słuszną" wykładnią filozoficzną chrześcijaństwa ${ }^{68}$. Tymczasem Tischner, reflektując polemikę $\mathrm{z}$ tomizmem, utrzymywał, że trzonem tej dyskusji był spór o realizm. Owszem, sądzi, że w wielu nurtach współczesnej filozofii pobrzmiewają tony idealizmu. Taki zarzut formułowano na przykład wobec Husserla. „Moi polemiści uważali, że filozofia chrześcijańska musi być realistyczna. [...] Ja próbowałem udowodnić, że realizm nie jest dogmatem chrześcijaństwa i że nie można bronić realizmu, twierdząc, iż bez niego nie ma chrześcijaństwa. Sam biskup Berkeley jest żywym przykładem, że może być inaczej”69.

Warto zwrócić uwagę, że za krytyką tomistycznego chrześcijaństwa, kryje się kryzys pewnej historycznej wersji chrześcijaństwa ${ }^{70}$. Tischner stawia tomizmowi zarzut, jakoby nie formułował nowych pytań w filozofii i nie inspirował nowych problemów naukowych, bowiem ten nurt filozofii nie dysponuje odpowiednią metodyką ${ }^{71}$. Zarzut Tischnera jest wymierzony wobec anachronizmu tej wersji filozofowania. Tomizm bowiem nie nadąża już za współczesnymi osiągnięciami wiedzy o człowieku i świecie - zwłaszcza poza wartościami średnimi - a zatem w skali „makro”, „mikro”, czy ostatnio - „nano". Trudno tu zatem o warunki wystarczające do zachowania wzajemnej kompatybilności czy jakiegoś typu odpowiedniości, przekładalności. Tomizm nie może sobie nadto przyswoić odkrycia intencjonalności, uprawia natomiast refleksję ontologiczną. $\mathrm{O}$ ile racją tischnerowskiego wariantu filozofowania była aksjologia, o tyle w tomizmie jest to metafizyka, zmierzająca do odkrycia

${ }^{65}$ Por. J. Gowin, Religia i ludzkie biedy. Ks. Tischnera spory o Kościót, Kraków 2003, s. 31.

${ }^{66}$ Por. S. Szary, Człowiek - podmiot dramatu. Antropologiczne aspekty filozofii dramatu Józefa Tischnera, Kęty 2005, s. 11; V. Possenti, Józef Tischner - kontestator tomi$z m u$, tłum. E. Zieliński, „Zeszyty Naukowe KUL”3(1984), s. 69-77.

${ }^{67}$ Por. A. Karoń-Ostrowska, Spotkanie, dz. cyt., s. 83.

${ }^{68}$ Por. Z. Kuderowicz, Józef Tischner-jako filozof i etyk, dz. cyt., s. 155; W. Krajewski, Dogmatyzm i krytycyzm w polskiej filozofii powojennej, „Ruch Filozoficzny” LXII/1(2005), s. 35.

${ }^{69}$ Cyt. za: A. Karoń-Ostrowska, Spotkanie, dz. cyt., s. 85n.

${ }^{70}$ Opinię tę podzielają S. Grygiel i J. Salij (por. J. Tischner, Myślenie wedtug warto$s ́ c i$, dz. cyt., s. 224n).

${ }^{71}$ Por. J. Tischner, Myślenie wedlug wartości, dz. cyt., s. 239. 
ostatecznych racji istnienia wszelkich zjawisk. Skrajnym zaś wykwitem (wypaczeniem) tomizmu może stać się postawa fundamentalistyczna ${ }^{72}$.

To, czego jednak może brakować w krytyce Tischnera, to pozytywne i nieco bardziej wnikliwe propozycje przeformułowania teologii. Nie odnajdziemy tu zatem preferencji „systemów” w ramach chrześcijaństwa. W tej kwestii autor jedynie szkicuje możliwości lub wytycza kierunki ${ }^{73}$. Spór Tischnera $\mathrm{z}$ tomizmem to, zdaniem Tadeusza Gadacza, raczej walka tego pierwszego $\mathrm{z}$ pewną formą ideologizacji myślenia religijnego. Spór ten odsłania bowiem mechanizmy, które sprawiają, że myślenie religijne może być ideologizowane, ale i pokazuje, jak można tego uniknąc ${ }^{74}$. Jeszcze przed ukazaniem się Schytku chrześcijaństwa tomistycznego, w 1961 roku, Karol Wojtyła pisał: „Doskonale widzimy u św. Tomasza osobę w jej obiektywnym bytowaniu i działaniu, ale trudno nam mówić o przeżyciach osoby" "75. Natomiast Tischner, komentując kryzys tomizmu, zauważa, że ów nurt stał się zbiorem pewnych formuł, które nie pomagają w rozstrzyganiu egzystencjalnych problemów. Aparat tomistycznych pojęć jest nadto zbyt abstrakcyjny i niezrozumiały. W rezultacie człowiek nie znajdzie na tym obszarze satysfakcjonujących wyjaśnień czy rozwiązañ ${ }^{76}$. Dla tomistów z kolei tischnerowska filozofia dramatu stanowi swoistą ,teorię egzystencjalistycznie ujmowanych przeżyć", które nie mogą być wiarygodnym źródłem ${ }^{77}$.

Wytyczając ewentualny kierunek badań na przyszłość, Tischner napisał: „Mogę zapewnić (...), że nigdy nie napisałbym czegoś podobnego do Schytku, gdybym nie był głęboko przekonany, że naprawdę fascynujące perspektywy filozoficzne dla chrześcijaństwa stoją dzisiaj przed nami, a nie za nami" ${ }^{\prime 78}$.

${ }^{72}$ Por. Z. Kuderowicz, Józef Tischner - jako filozof $i$ etyk, dz. cyt., s. 155n; M. Bielawski, Teologiczne manowce Tischnera, „Znak”3(2001), s. 10.

${ }^{73}$ Por. J. Tischner, Myślenie wedtug wartości, dz. cyt., s. 239.

${ }^{74}$ Por. T. Gadacz, Tischnerowskie spojrzenia, „Znak” 5(2004), s. 34. Zdaje się jednak, że w pewnych sformułowaniach Tischnera uwidaczniają się także pierwiastki ideologizacji.

${ }^{75}$ Por. K. Wojtyła, Personalizm tomistyczny, w: tenże, „, Aby Chrystus się nami postugiwat”, Kraków 1979, s. 436; T. Gadacz, Chrześcijańskie korzenie Tischnerowskiej filozofii czlowieka, „Znak” 5(2004), s. 79.

${ }^{76}$ Por. A. Karoń-Ostrowska, Spotkanie, dz. cyt., s. 82; E. Husser1, Kryzys nauk europejskich i fenomenologia transcendentalna, tłum. S. Walczew ska, Torun 1999, s. 19n.

${ }_{77}$ Por. M. Gogacz, Trzeba powrócić do realistycznej metafizyki, w: Rozmowy o filozofii, dz. cyt., s. 83 .

${ }^{78}$ Por. J. Tischner, Myślenie wedlug wartości, dz. cyt., s. 239. 


\section{JOSEPH TISCHNER'S POSITION TOWARDS THOMISM}

\section{Summary}

Famous article of Tischner "The Decline of Christianity Thomist", published on pages of the monthly the "Znak" in 1970 evoked the wave of interesting polemics in the Polish philosophical environment. They concerned on one hand the role of the Thomism in contemporary theology, on the other the criticism of the position of Tischner. Very author responded to a challenge criticizing the Thomism as the synthesis of data of the Revelation and Aristotelian philosophy. Because this merger is seizing character of both above ingredients - compared to two colours mixt with oneself and in the end constituting the new colour. Thomistic synthesis, from Tischner's perspective, came into existence in the crowning moment of the history of the Christianity in Europe. She agreed on contemporary models of the scientific nature, culture, forms of the statehood. However in our times dangerous of it is a result uniquely thomistic "becoming poor" not to say "perversion" Christianities. And so in our times would the new synthesis be desired? Through the division of the learning, took the place of universal syntheses different "microsystems", and very idea of the synthesis turned out to be too ambiguous, and for her conditions are impossible to fulfil. Valuable however rapidly of Tischner there would be rather a hermeneutic proposal of Paul of Ricoeur indeed to concentrate on the text of the christian revelation without the thomistic dogmatism here. Hence also, however dusk of the Thomism is opening intriguing and the philosophical latest perspectives for the Christianity.

\section{Keywords:}

thomism, thomistic synthesis, scientific synthesis, speculative theology, metaphysics, christianity, christian revelation 
